\title{
Laboratory Measurement of Hazardous Fumes and Gases at a Point Corresponding to Breathing Zone of Welder during a $\mathrm{CO}_{2}$ Arc Welding
}

\author{
Hiroyuki SAITO ${ }^{*}$, Jun OJIMA ${ }^{1}$, Mitsutoshi TAKAYA ${ }^{1}$, Takeshi IWASAKI ${ }^{1}$, \\ Naomi HISANAGA ${ }^{1}$, Shigeru TANAKA ${ }^{2}$ and Heihachiro ARITO ${ }^{1}$
}

\author{
${ }^{1}$ National Institute of Industrial Health, 21-1, Nagao 6-chome, Tama-ku, Kawasaki 214-8585, Japan \\ ${ }^{2}$ School of Allied Health Sciences, Kitasato University
}

Received October 5, 1999 and accepted November 29, 1999

\begin{abstract}
Concentrations of fumes, ozone $\left(\mathrm{O}_{3}\right)$, carbon monoxide $(\mathrm{CO})$, nitric oxide (NO), manganese (Mn) and total and hexavalent chromium $(\mathrm{Cr})$ as well as size distribution of fumes were measured at a point corresponding to the welder's breathing zone during $\mathrm{CO}_{2}$-arc welding, using a welding robot and three kinds of wires. Concentrations of fumes, $\mathrm{O}_{3}, \mathrm{CO}, \mathrm{Mn}$ and total-Cr were found to exceed their corresponding occupational exposure limit (OEL) values, while the concentrations of NO and $\mathrm{Cr}$ (VI) were below those OEL levels. Airborne concentration of Mn exceeded its OEL value, and the Mn content was 8 times higher in welding fumes than in the wire. Using an additive equation of OEL and exposure concentration of each hazardous component, health risk in welders with combined exposure to welding fumes and gases was assessed as 18.6 to 46.0 times of OEL, which exceeded the unity. This finding suggests that effective protection of welders from the exposure can be attained by use of the supplied-air respirator or combined use of a dust respirator and a local exhaust system.
\end{abstract}

Key words: $\mathrm{CO}_{2}$ arc welding, Welding fumes, Ozone, Carbon monoxide, Nitric oxide, Manganese, Chromium, Combined exposure

\section{Introduction}

Welding is one of the most important trades, employing 700,000 and 400,000 in the U.S. ${ }^{1)}$ and Japan, respectively. Welding is a high-risk occupation; welders are exposed to hazardous fumes and gases during welding operation and tends to suffer from occupational respiratory diseases such as welding pneumoconiosis and asthma ${ }^{2-5}$. Donoghue $e t$ $a l .{ }^{6}$ reported that the peak expiratory flow (PEF) of the welder was significantly decreased as compared to a control group, and that their signs and symptoms were similar to the occupational asthma. Wolf et al. ${ }^{5)}$ showed that the mean expiratory flows of the welders at the $25 \%$ and $50 \%$ levels $\left(\mathrm{MEF}_{25}, \mathrm{MEF}_{50}\right)$ were significantly decreased compared to

\footnotetext{
*To whom correspondence should be addressed.
}

the control group. Ohmori et al. ${ }^{7)}$ demonstrated that the decreases in the maximum expiratory flow rate at $25 \%$ and $50 \%$ of vital capacities $\left(\dot{\mathrm{V}}_{25}, \dot{\mathrm{V}}_{50}\right)$ were significant for the welder groups, indicating that welding operations producing comparatively high concentrations of ozone $\left(\mathrm{O}_{3}\right)$ would cause occlusive impairment of the welders' bronchioles.

In addition to other harmful physical factors such as ultraviolet and infrared radiation and noise, hazardous and reactive chemical substances are generated during welding. These include gaseous substances such as $\mathrm{O}_{3}$, carbon monoxide $(\mathrm{CO})$, and nitric oxides and particulates such as iron $(\mathrm{Fe})$, chromium $(\mathrm{Cr})$, nickel $(\mathrm{Ni})$, manganese $(\mathrm{Mn})$ and copper $(\mathrm{Cu})$ and their oxides ${ }^{1}$. Ulfvarson and $\mathrm{Tech}^{8}$ showed that the dayaveraged concentrations of fumes at a breathing zone during the metal inert gas welding (MIG) operation on aluminum and the manual metal arc welding (MMA) operation on mild 
steel were highest, leveling off at $10 \mathrm{mg} / \mathrm{m}^{3}$, during the tungsten inert gas welding (TIG) operation on aluminum or stainless steel were lowest, leveling off at $1-2 \mathrm{mg} / \mathrm{m}^{3}$. Wal ${ }^{9)}$ showed that the average concentrations of fumes were $5.3 \mathrm{mg} / \mathrm{m}^{3}$ for MMA on mild steel, $4.4 \mathrm{mg} / \mathrm{m}^{3}$ for MIG/MAG (metal active gas) welding on mild steel and $1.4 \mathrm{mg} / \mathrm{m}^{3}$ for TIG welding on stainless steel, and that the highest concentration of $\mathrm{Cr}(\mathrm{VI})$ was $1.5 \mathrm{mg} / \mathrm{m}^{3}$, and highest concentration of nickel was 0.21 $\mathrm{mg} / \mathrm{m}^{3}$ for MMA on stainless steel. Ohmori et al. ${ }^{7)}$ showed that the mean concentration of $\mathrm{O}_{3}$ at a breathing zone was $1.27 \mathrm{ppm}$ for MIG on aluminum and $0.28 \mathrm{ppm}$ for $\mathrm{CO}_{2}$ arc welding on mild steel. It can be surmised from the above reports that hazardous substances generated during welding operations differ in quality and quantity, depending on welding methods, processes and materials. It is, therefore, of prime importance to identify health risks by chemical analysis of substances to which welders might be exposed.

The present study was intended to determine welding fumes and gases as well as size distribution of the fumes during a $\mathrm{CO}_{2}$ arc welding operation. In this study, we used an automatic welding robot with three kinds of wire electrodes, and took the samples of fumes and gases at a point corresponding to a welder's breathing zone.

\section{Materials and Methods}

\section{Welding process}

A welding robot (ARCMAN-RON, Kobe Steel Co. Ltd., Japan) was used in the present study. Three kinds of consumable electrodes: solid wire (Kobe Steel MG-50T, $\phi 1.2$ mm, JIS Z 3312 YGW12) for mild steel, flux-cored wire (Kobe Steel DW-Z100, $\phi 1.2$ mm, JIS Z 3313 YFW-C50DR) for mild steel and solid wire (Cr 5\%-Mo 0.5\%, Kobe Steel MGS-5CM, $\phi 1.2$ mm, JIS Z 3317 YG5CM-A) for Cr-Mo steel were used for the "bead-on-plate" $\mathrm{CO}_{2}$ arc welding on a mild steal plate $(250 \mathrm{~mm} \times 250 \mathrm{~mm} \times 10 \mathrm{~mm}$, JIS G 3101 SS400). As shown in Fig. 1, an arc point was moved at a constant speed in a zigzag manner. The flow rate of shielding $\mathrm{CO}_{2}$ gas and the welding current were fixed at $20 \mathrm{~L} / \mathrm{min}$ and 200 amperes in 25 volts, respectively. The welding operation was performed in a laboratory $(6 \mathrm{~m} \times 15.5 \mathrm{~m} \times$ $3.6 \mathrm{~m})$ without local exhaust ventilation.

\section{Sampling point}

Samples of welding fumes and gases were taken with a synchronously moving sampling point of $200 \mathrm{~mm}$ horizontal distance and $300 \mathrm{~mm}$ vertical distance from the moving arc point. The sampling point was assumed to correspond to a

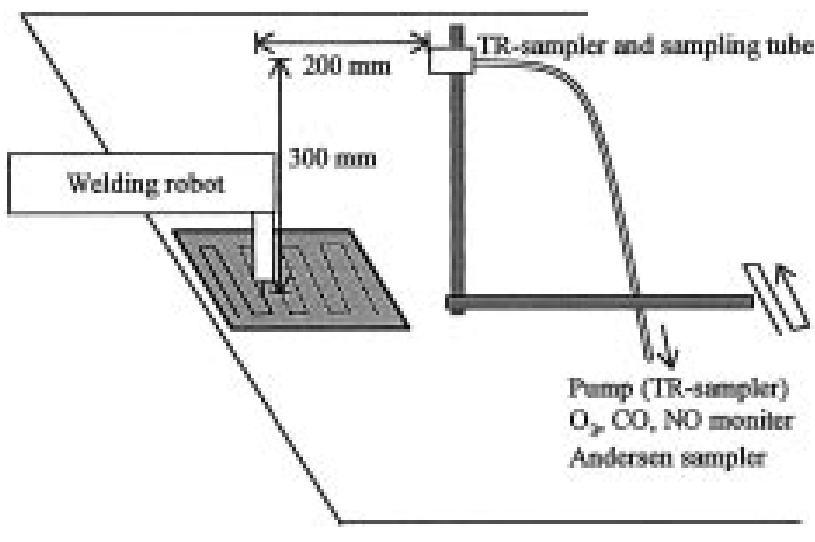

Fig. 1. A schematic diagram of welding operation and sampling. Welding fumes and gases were sampled at a synchronously moving sampling point of $200 \mathrm{~mm}$ horizontal distance and $300 \mathrm{~mm}$ vertical distance from the moving arc point.

welder's breathing zone when manual operation was performed for the $\mathrm{CO}_{2}$ arc welding.

\section{Measurements of gaseous concentrations}

Concentrations of $\mathrm{O}_{3}, \mathrm{CO}$, and nitric oxide (NO) were measured with a $\mathrm{UV} \mathrm{O}_{3}$ monitor (EG-2001F, Ebara Jitsugyo Co., Japan) calibrated by the potassium iodide method ${ }^{10)}$, a CO monitor of polarographic type ${ }^{11-14)}$ (CO-85FL, Riken Keiki Co., Japan), and a NO monitor of polarographic type $^{13,14)}$ (SC-90, Riken Keiki Co., Japan), respectively. The concentration of each gas was measured at 15-second intervals for a 10-min period consisting of 6.3 minutes welding, and 3.7 minutes post welding recess, and calculated for an arithmetic mean with 10 repeated trials under the same welding conditions.

\section{Measurement of fumes concentration}

An aerosol sampling device of Roken type ${ }^{15)}$ (TR-Sampler, Sibata Scientific Technology, Japan) with attached glass plate and a Teflon binding glass fiber filter (T60A20, Pallflex Products Corp) was used to separately collect total welding fumes and its respirable component of smaller than $7 \mu \mathrm{m}$, respectively. The glass plate was coated with a mixture of silicone grease and silicone oil. Fumes were collected on the glass fiber filter at a flow rate of $20 \mathrm{~L} / \mathrm{min}$ during the welding operation.

\section{Measurement of particle size distribution}

Welding fumes were collected with an Andersen sampler ${ }^{16)}$ with attached Teflon binding glass fiber filter (T60A20, Pallflex Products Corp.). Fumes were collected on the filter at a flow 


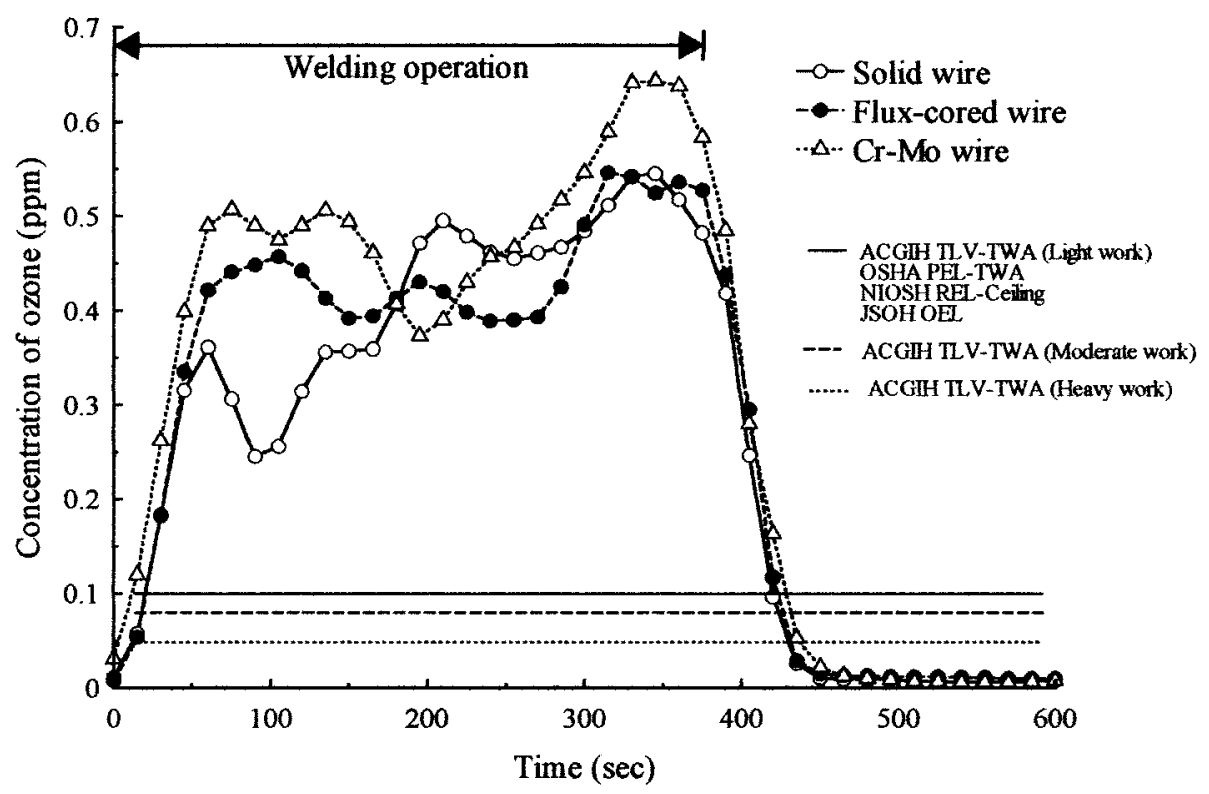

Fig. 2. Time-course changes in $O_{3}$ concentrations at a point corresponding to the welder's breathing zone. Each symbol indicates an arithmetic mean of 10 welding operations for each wire. Open circles $(\bigcirc)$, filled circles ( ) and open triangles $(\triangle$ ) indicate solid, flux-cored and Cr-Mo wires, respectively.

rate of $26.7 \mathrm{~L} / \mathrm{min}$. The aerodynamic diameter of fumes was determined by a change in weight of the filter before and after fume collection at each stage of the Andersen sampler.

\section{Concentration of $\mathrm{Cr}$ and $\mathrm{Mn}$ in fumes}

Welding fumes were collected with an open face lowvolume air sampler (Filter Holder type-B, Sibata Scientific Technology Inc., Japan) with nitrocellulose membrane filter (FNWW80, Fuji Photo Film Co., pore size $0.8 \mu \mathrm{m}$ ) at a flow rate of $10 \mathrm{~L} / \mathrm{min}$. Fumes on the filter were dissolved in a hot aqua regia solution $\left(\mathrm{HCl}+\mathrm{HNO}_{3}, 3: 1\right)$, and determined for contents of total $\mathrm{Cr}$ and $\mathrm{Mn}$ in an inductively coupled plasma atomic emission spectrometry (ICP-AES, JY-138, Horiba, Kyoto, Japan). The contents of total $\mathrm{Cr}$ and $\mathrm{Mn}$ in the wires were determined by the same analytical method after the wires were dissolved in the hot aqua regia solution. Hexavalent $\mathrm{Cr}$ (Cr(IV)) in the welding fumes was analyzed according to the same method described above, except that fumes were collected with a Teflon binding glass fiber filter (T60A20, Pallflex Products Corp.). Content of $\mathrm{Cr}(\mathrm{VI})$ was determined by the method described by Sawatari and Serita ${ }^{17)}$.

\section{Results}

\section{Welding gases}

Figure 2 shows time-course changes in mean $\mathrm{O}_{3}$
Table 1. Time-average concentrations of $\mathrm{O}_{3}, \mathrm{CO}$, and NO during the welding operation

\begin{tabular}{lccc}
\hline & $\mathrm{O}_{3}(\mathrm{ppm})$ & $\mathrm{CO}(\mathrm{ppm})$ & $\mathrm{NO}(\mathrm{ppm})$ \\
\hline Solid wire & $0.42 \pm 0.15$ & $89.9 \pm 36.0$ & $1.69 \pm 0.66$ \\
Flux-cored wire & $0.44 \pm 0.18$ & $79.7 \pm 37.8$ & $1.88 \pm 1.21$ \\
Cr-Mo wire & $0.50 \pm 0.22$ & $78.8 \pm 35.4$ & $1.18 \pm 1.24$ \\
\hline
\end{tabular}

The concentrations of each substance collected at a $15 \mathrm{sec}$ interval from $15 \mathrm{sec}$ after start of welding to the end of the welding operation were averaged over the welding time period. Each value indicates an arithmetric mean and SD of 10 welding operations for each wire.

concentrations during the welding operation with the three kinds of electrode wires at a sampling point corresponding to the welder's breathing zone. $\mathrm{O}_{3}$ concentration was abruptly increased to 0.4 to $0.6 \mathrm{ppm}$ immediately after the start of the welding operation, then reached to a plateau, and then declined rapidly after cessation of the welding operation. As shown in Table 1, the time-averaged concentrations of $\mathrm{O}_{3}$ ranging from 0.4 to $0.5 \mathrm{ppm}$ over a $6.3 \mathrm{~min}$ period of welding operation were independent of the wires used, because there was no statistical difference in $\mathrm{O}_{3}$ concentration among the three kinds of wires.

Figure 3 shows time-course changes in mean $\mathrm{CO}$ concentrations during welding operation with the three kinds of wires. The CO concentrations tended to increase gradually 


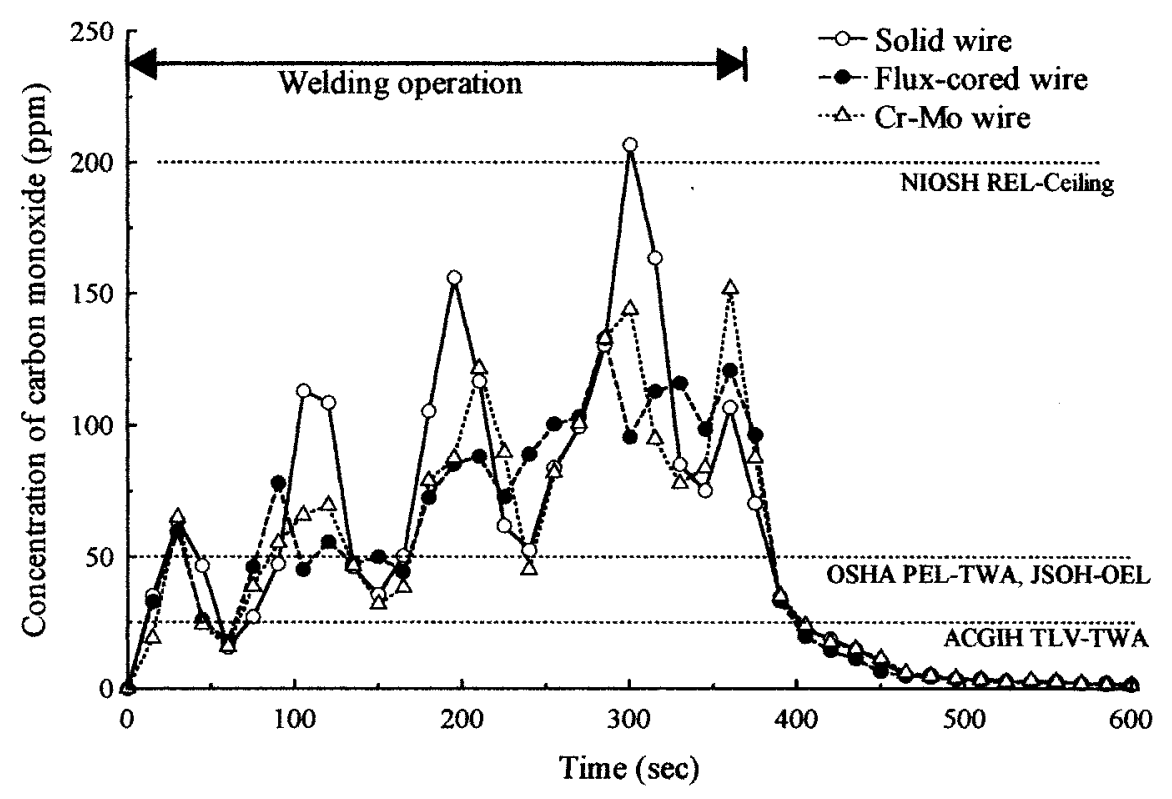

Fig. 3. Time-course changes in $\mathrm{CO}$ concentrations at a point corresponding to the welder's breathing zone. Each symbol indicates an arithmetic mean of 10 welding operations for each wire. The symbols are the same as those in Fig. 2.

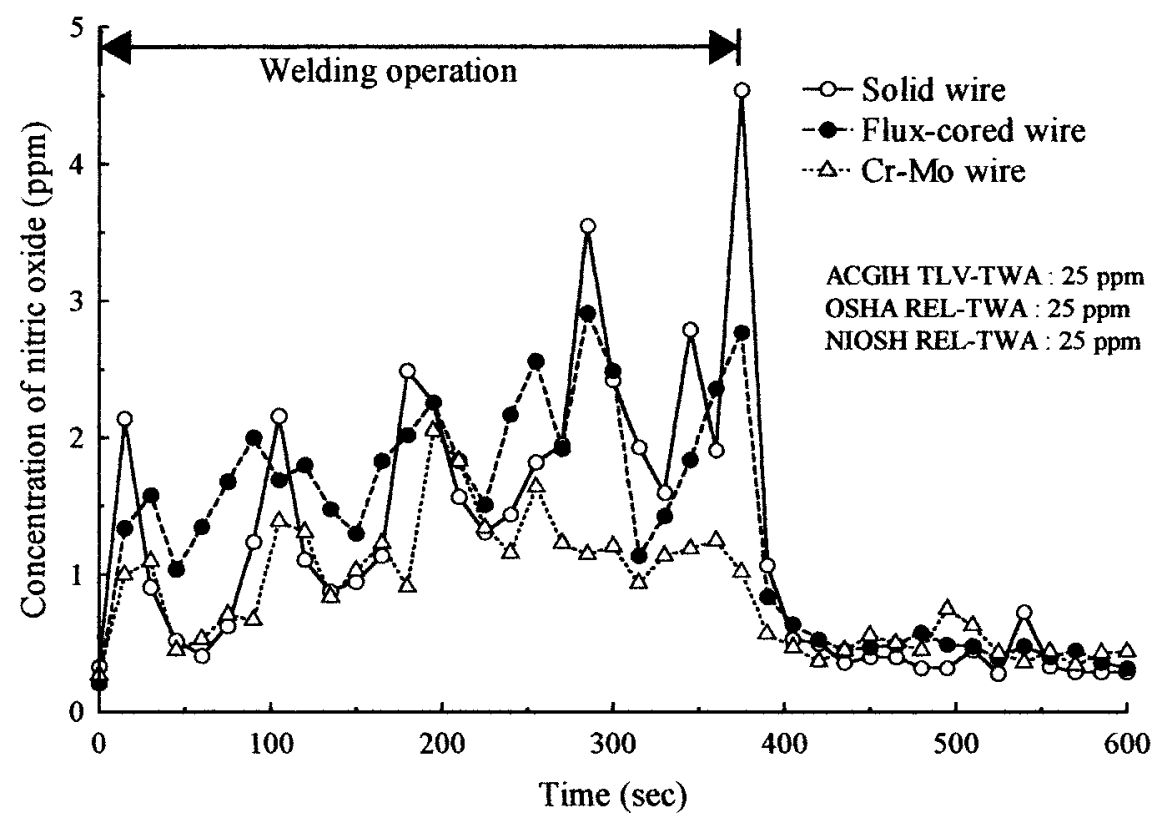

Fig. 4. Time-course changes in NO concentrations at a point corresponding to the welder's breathing zone. Each symbol indicates an arithmetic mean of 10 welding operations for each wire. The symbols are the same as those in Fig. 2.

and cyclically during the course of welding. The timeaveraged $\mathrm{CO}$ concentration was found in the range from 78.8 to $89.9 \mathrm{ppm}$ for the three kinds of wires, indicating that there was no statistical difference in $\mathrm{CO}$ concentration among the three wires.

Time-course changes in mean NO concentration during welding with the three kinds of wires are shown in Fig. 4, indicating that the NO concentration increased in the same 


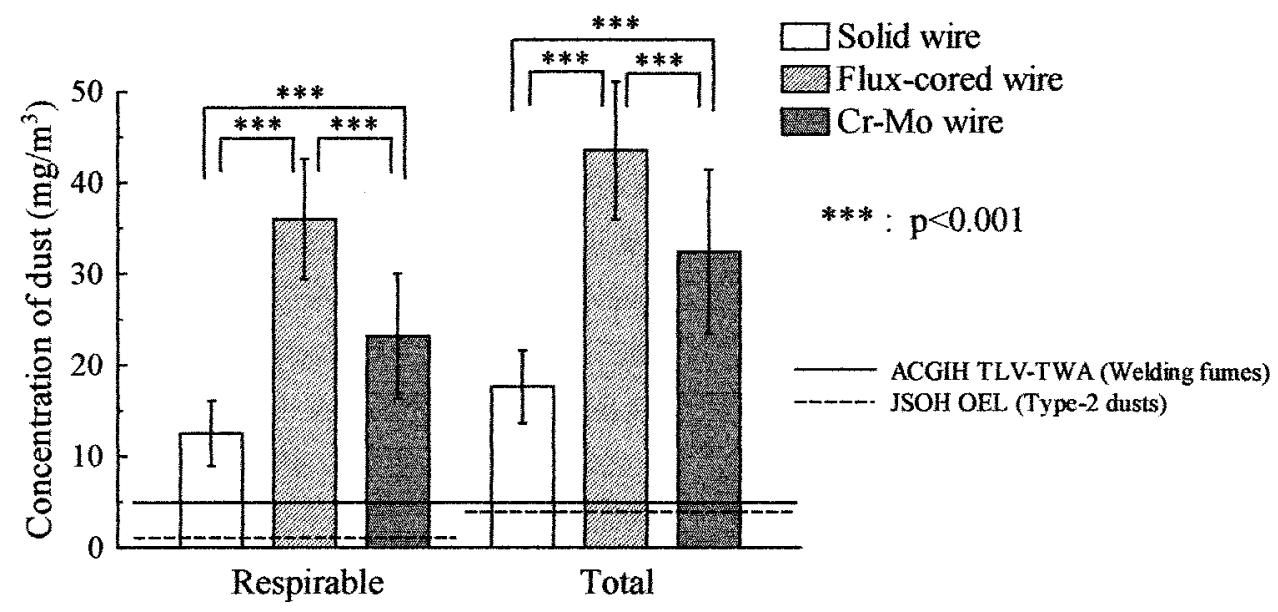

Fig. 5. Concentrations of respirable and total fumes at a point corresponding to the welder's breathing zone. Each bar with a vertical bar indicates an arithmetic mean and S.D of 10 welding operations for each wire. Open

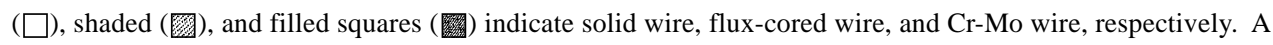
triple asterisk indicates statistical significance at a level of $\mathrm{p}<0.001$ by Tukey's multiple comparison method.

manner as $\mathrm{CO}$ concentrations. The time-averaged NO concentration was found to range from 1.18 to $1.88 \mathrm{ppm}$, and there was no statistical difference in NO concentrations among the three kinds of wires.

\section{Welding fumes}

Figure 5 shows concentrations of total welding fumes and their respirable component at a point corresponding to the welder's breathing zone during the welding operation with the three wires. The concentrations of both total fumes and its respirable component increased in the order of solid wire, Cr-Mo wire and flux-cored wire. The amount of generated fumes was significantly greater for the flux-cored wire than for the other two wires and was lowest for the solid wire. The ratios of the respirable component to the total fumes were found to range from $70 \%$ for the solid wire, $72 \%$ for the $\mathrm{Cr}$-Mo wire to $83 \%$ for the flux-cored wire.

The particle size distributions of welding fumes collected in the welder's breathing zone during the welding operation with the three kinds of wires are shown in Fig. 5. The mean aerodynamic diameter of fumes was approximately $0.5 \mu \mathrm{m}$ for the three kinds of wires. The two lines with different slopes shown in Fig. 5 indicate that there are two different size distributions of fine particles of diameter less than 1 $\mu \mathrm{m}$, and coarse particles of greater than $1 \mu \mathrm{m}$.

Contents of $\mathrm{Mn}$ and total $\mathrm{Cr}$ in both the welding fumes and the wires are given in Table 2. The results of analysis of the metal contents of the three kinds of wires were in good agreement with the nominal contents (Mn in the solid

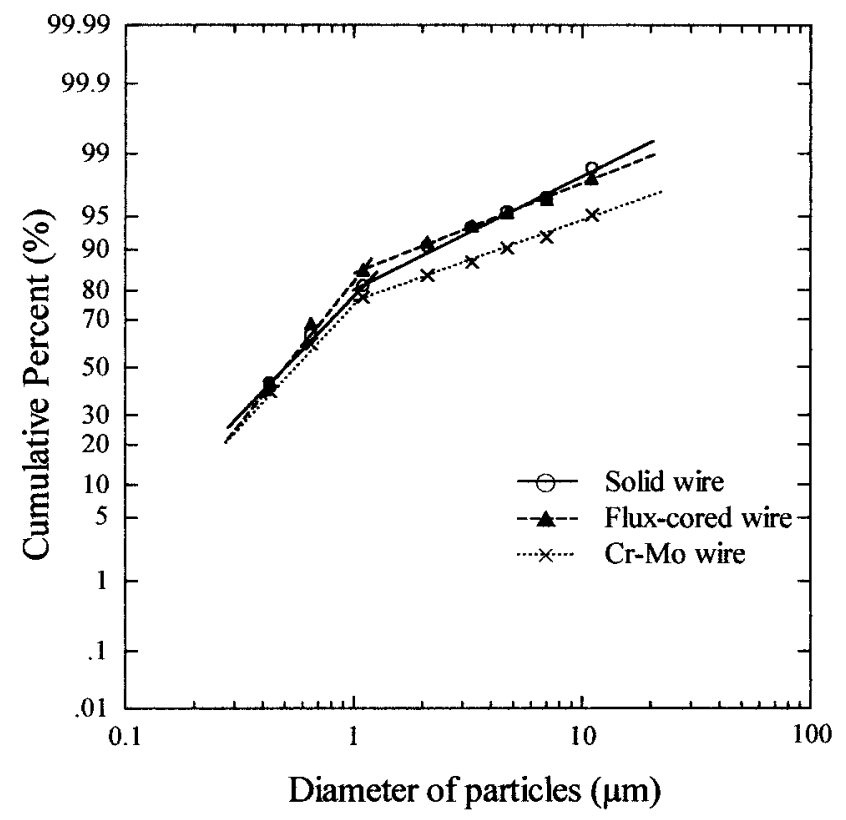

Fig 6. Distribution of aerodynamic diameter of welding fumes at a point corresponding to the welder's breathing zone.

Each symbol indicates an arithmetic mean of 10 welding operations for each wire.

wire: $1.25-1.90 \%, \mathrm{Mn}$ in the flux-cored wire: $<2.00 \%, \mathrm{Mn}$ in the Cr-Mo wire: $0.20-1.30 \%$ and $\mathrm{Cr}$ in the Cr-Mo wire: $4.50-6.00 \%)$ as regulated by the Japanese Industrial Standards. It is worthy of note that the Mn contents were 7.7 to 8.6 times greater in the welding fumes than in the wires. On the other hand, there was no difference in the $\mathrm{Cr}$ 
Table 2. Contents of $\mathrm{Mn}$ and $\mathrm{Cr}$ in each wire and each fume, and ratio of contents of $\mathrm{Mn}$ and $\mathrm{Cr}$ between each fume and wire

\begin{tabular}{llcc}
\hline & & $\mathrm{Mn}$ & $\mathrm{Cr}$ \\
\hline \multirow{3}{*}{ Solid wire } & Wire & $1.35 \%$ & \\
& Fume & $10.4 \%$ & - \\
& Ratio of Fume/Wire & 7.7 & \\
\hline \multirow{3}{*}{ Flux-cored wire } & Wire & $2.19 \%$ & \\
& Fume & $18.9 \%$ & - \\
& Ratio of Fume/Wire & 8.6 & \\
\hline \multirow{3}{*}{ Cr-Mo wire } & Wire & $0.46 \%$ & $4.98 \%$ \\
& Fume & $3.62 \%$ & $5.56 \%$ \\
& Ratio Fume/Wire & 7.9 & 1.1 \\
\hline
\end{tabular}

Each value indicates an arithmetric mean of 10 welding operations for each wire.

content between welding fumes and Cr-Mo wire.

As shown in Fig. 7, the Mn concentration in total welding fumes and their respirable component were the highest for the flux-cored wire, followed by the solid wire and the $\mathrm{Cr}$ Mo wire. Total $\mathrm{Cr}$ and $\mathrm{Cr}(\mathrm{VI})$ contents in welding fumes and their respirable component during welding with the $\mathrm{Cr}$ Mo wire are shown in Fig. 8. The total Cr content was 1.6 $\mathrm{mg} / \mathrm{m}^{3}$ in welding fumes and $1.3 \mathrm{mg} / \mathrm{m}^{3}$ in their respirable component, while the $\mathrm{Cr}(\mathrm{VI})$ content was $0.0035 \mathrm{mg} / \mathrm{m}^{3}$ in the fume and $0.0028 \mathrm{mg} / \mathrm{m}^{3}$ in its respirable component. $\mathrm{Cr}$ was not detected in either solid wire or flux-cored wire.

\section{Discussion}

To assess health risks due to exposure to hazardous substances in the workplace, exposure duration is another important determinant in addition to the ambient air concentrations of generated substances. The actual amount of time a welder engages in welding in a workday varies from place to place and from day to day. Since the occupational exposure limit (OEL) values of all the substances analyzed here are designated according to the time-weighted average in American Conference of Governmental Industrial Hygienists (ACGIH TLV-TWA), excursions in exposure levels may exceed 3 times the TLVTWA for no more than a total of 30 minutes during a workday ${ }^{18)}$. In the present study, we used an excursion limit value $(3 \times$ TLV-TWA $)$ as a reference value to compare airborne concentration of welding fumes and gases, in order to assess health risk of workers exposed to welding fumes and gases during welding.

\section{Welding gases}

In the present study, $0.42-0.50 \mathrm{ppm} \mathrm{O}_{3}$ was observed at a point corresponding to the welder's breathing zone during the $\mathrm{CO}_{2}$ arc welding. This $\mathrm{O}_{3}$ level was 2.8-3.3 times higher than the excursion limit of TLV-TWA ( $0.05 \mathrm{ppm}$, Heavy work). Ohmori et al. ${ }^{7)}$ reported a significant decrease of $\dot{\mathrm{V}}_{25}$ in welders who had been exposed to $1.05 \mathrm{ppm} \mathrm{O}_{3}$ or more. McDonnell et al. ${ }^{21)}$ reported significant decreases of

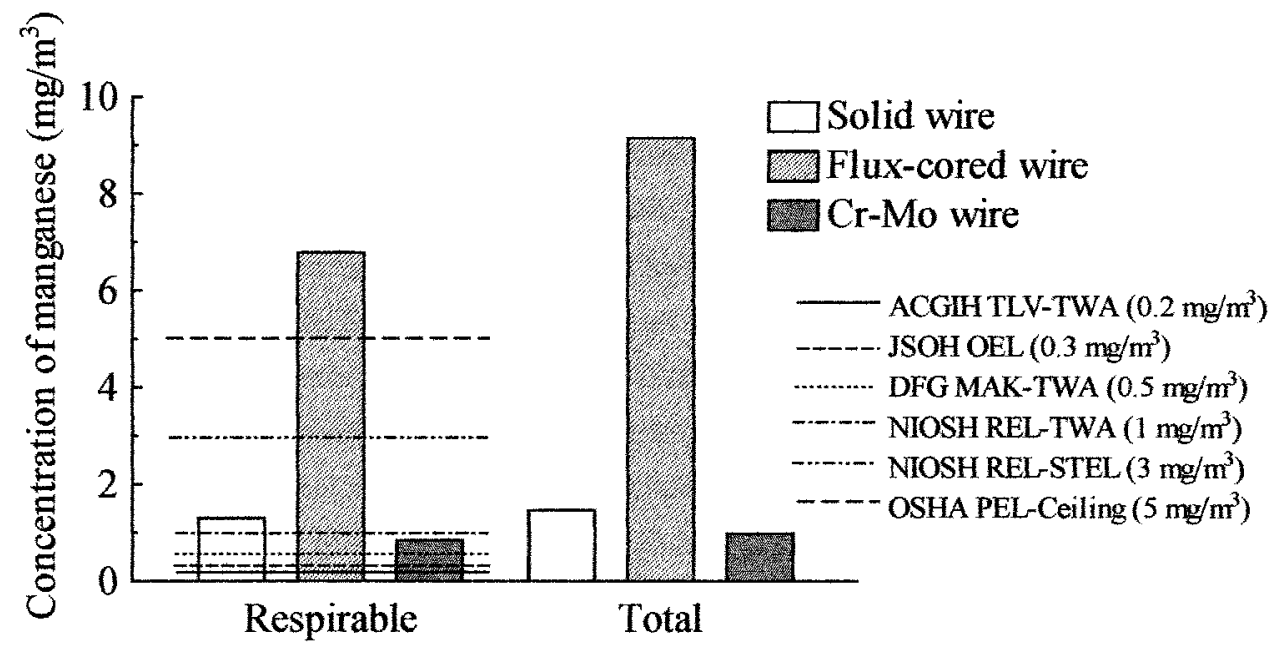

Fig. 7. Concentrations of respirable and total Mn at a point corresponding to the welder's breathing zone. Each bar indicates an arithmetic mean of 10 welding operations for each wire. Open ( $\square$ ), shaded (笅) and filled squares (閿) indicates the solid wire, flux-cored wire and Cr-Mo wire, respectively. 

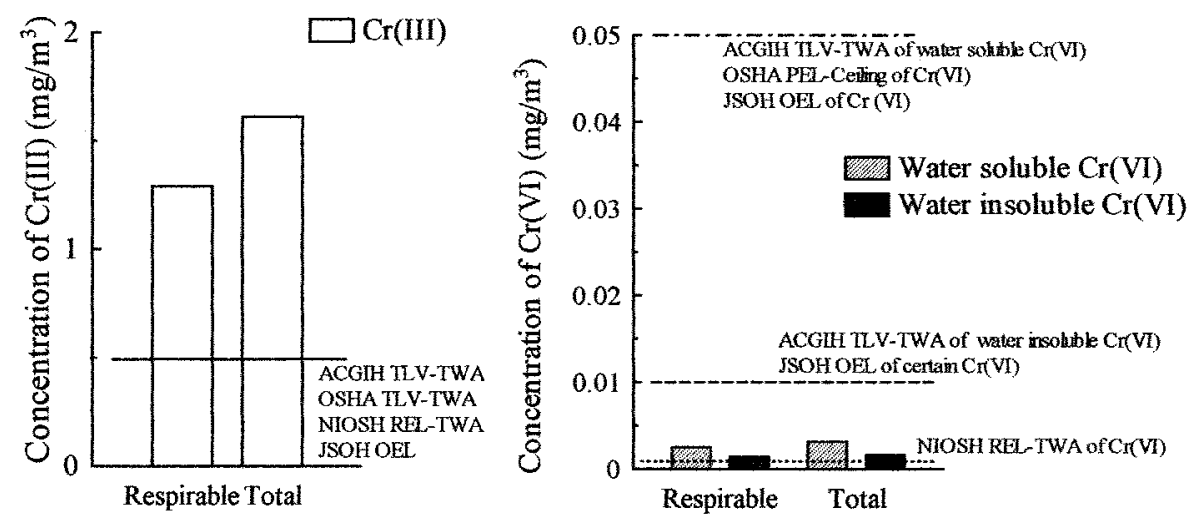

Fig. 8. Concentrations of $\mathrm{Cr}(\mathrm{III})$, water soluble $\mathrm{Cr}(\mathrm{VI})$ and water insoluble $\mathrm{Cr}(\mathrm{VI})$ at a point corresponding to the welder's breathing zone.

Each bar indicates an arithmetic mean of 10 welding operations for Cr-Mo wire. Open ( $\square$ ), shaded (国) and filled squares $(\square)$ indicates the $\mathrm{Cr}(\mathrm{III})$, water soluble $\mathrm{Cr}(\mathrm{VI})$, and water insoluble $\mathrm{Cr}(\mathrm{VI})$, respectively.

$\mathrm{FVC}, \mathrm{FEV}_{1.0}$, and forced expiratory flow $\left(\mathrm{FEF}_{25-75}\right)$ and increase of the subjective symptom with 2.5 hours exposure at $0.12-0.40 \mathrm{ppm} \mathrm{O}_{3}$. McDonell et al. ${ }^{22)}$ and Horstman et $a l .{ }^{23)}$ reported the significant decrease of $\mathrm{FVC}, \mathrm{FEV}_{1.0}$ and $\mathrm{FEF}_{25-75}$ with 6.6 hours exposure at $0.06 \mathrm{ppm} \mathrm{O}_{3}$. Therefore, it can be inferred from the results of the above-mentioned reports that $\mathrm{O}_{3}$ levels of $0.4-0.5 \mathrm{ppm}$ found in the present study cause some detrimental health effects on welders' respiratory functions if no respiratory protective equipment is worn. Ambient levels of ozone produced during welding are thought to depend not only upon welding methods and weld materials, but also upon the space where welding is done. For example, higher $\mathrm{O}_{3}$ levels are reported to emanate during the tungsten inert gas (TIG) arc welding on non-ferrous metals ${ }^{24,25)} \cdot \mathrm{O}_{3}$ levels are expected to be higher in any confined space than in an open space such as that used in the present experiment. Therefore, it is recommended that the respiratory protective equipment attached to an activated charcoal filter be worn for arc welding operations, because the activated charcoal filter is shown to effectively remove ozone ${ }^{26,27)}$.

It has been reported that $1-2 \%$ of $\mathrm{CO}_{2}$ used for the inert shielding gas was decomposed to $\mathrm{CO}$ by ultraviolet light and heat ${ }^{28)}$. In the present study, the time-averaged concentration of $\mathrm{CO}$ was found in the range from 78 to 90 $\mathrm{ppm}$, and thus is equivalent to the excursion limit of OEL for CO set by ACGIH TLV-TWA (25 ppm). According to the report of Peterson and Stewart ${ }^{29)}$, concentration of carboxyhemoglobin $(\mathrm{COHb})$ in blood can be estimated by both exposure time (min) and concentration (ppm), using the following equation:

$$
\% \mathrm{COHb}=\left(\mathrm{CO}^{0.858} \mathrm{t}^{0.63}\right) / 197 .
$$

Since CO was found to amount to 80-90 ppm during welding, it can be calculated from the above equation that $1-\mathrm{hr}$ and 8-hr exposures of a welder to $\mathrm{CO}$ result in blood $\mathrm{COHb}$ concentrations of $3 \%$ and $11 \%$, respectively. The suppressive effects on the central nervous system such as visual disorder and disorder of coordinated movement in extremities were reported to appear at about $5 \%$ of blood $\mathrm{COHb}$ concentration $^{30}$. Using the above equation, $5 \%$ blood $\mathrm{COHb}$ may correspond to exposure of welders for $2.5 \mathrm{hrs}$ to the CO level of 80-90 ppm found in the present study. Therefore, it is recommended on the basis of the present finding that a local exhaust system be used and that $\mathrm{CO}_{2}$-arc welding sessions of longer than $3 \mathrm{hrs}$ duration be restricted, unless supplied-air respirators are worn.

In the present study, it was found that 1.2-1.9 ppm NO was produced during $\mathrm{CO}_{2}$ arc welding. Those levels were below the OEL value for NO (ACGIH TLV-TWA, 25 ppm).

\section{Welding fumes}

It was found in the present study that concentrations of welding fumes vary from 17.7 to $43.6 \mathrm{mg} / \mathrm{m}^{3}$, depending upon the wires used. Those levels were 1.2 to 2.9 times as high as the excursion limit of ACGIH TLV-TWA $\left(5 \mathrm{mg} / \mathrm{m}^{3}\right.$, as welding fumes). The flux-cored wire produced the highest concentration of fumes, followed by the $\mathrm{Cr}$-Mo wire, and solid wire.

The two different lines shown in Fig. 5 can be taken to 
indicate a possibility that different mechanisms exist for formation of fumes: the smaller welding fume particles are formed by condensation of vaporized metals, while the coarse particles are produced secondarily by agglomeration of the fine particles. Fine particles of smaller than $1 \mu \mathrm{m}$ were made up $85 \%$ of total welding fumes.

Mn contents in welding fumes of respirable size $(<7 \mu \mathrm{m})$ were found to far exceed the OEL value of Mn at the breathing zone for all three kinds of wires. The highest level was $6.78 \mathrm{mg} / \mathrm{m}^{3}$ with the flux-cored wire, which was 11.3 times as high as the excursion limit of ACGIH TLV-TWA (0.2 $\mathrm{mg} / \mathrm{m}^{3}$ ). It was worthy to note that the Mn content was 7.78.6 times greater in the welding fumes than in the wire, while there was no difference in the $\mathrm{Cr}$ content between the fumes and the wire. Higher Mn content in the fumes is presumably caused by low boiling point of $\mathrm{Mn}\left(2151^{\circ} \mathrm{C}\right)$ in comparison with the boiling points of iron $\left(\mathrm{Fe}, 2735^{\circ} \mathrm{C}\right)$ and $\mathrm{Cr}$ $\left(2842^{\circ} \mathrm{C}\right)^{31)}$. Long-term exposure of workers to $\mathrm{Mn}$ is known to cause chronic manganism like the Parkinson's syndrome ${ }^{32)}$. Yim et al. ${ }^{33)}$, Lee et al. ${ }^{34)}$ and Kang et al. ${ }^{35)}$ reported that long-term exposure of welders to welding fumes causes abnormal neurological signs together with high blood level of Mn and abnormal MRI image. Boshnakova et al. ${ }^{36)}$ reported a significant decrease in immune functions among workers exposed to $0.29-0.46 \mathrm{mg} / \mathrm{m}^{3}$ of $\mathrm{Mn}$, vibration and noise. Because the Mn contents in welding fumes found in the present study were found to be substantially higher than the OEL value, health risk of welders developing to Parkinson's syndrome like disease and impaired immune function would be increased unless an effective respirator be worn. When the Cr-Mo wire was used for the $\mathrm{CO}_{2}$ arc welding, the $\mathrm{Cr}$ content of respirable size of particles $(<7$ $\mu \mathrm{m}$ ) was $1.3 \mathrm{mg} / \mathrm{m}^{3}, 80 \%$ of total dust, and the contents of water soluble $\mathrm{Cr}(\mathrm{VI})$ and water insoluble $\mathrm{Cr}(\mathrm{VI})$ was only $0.2 \%$ and $0.1 \%$ of total $\mathrm{Cr}$, respectively. The levels of water soluble $\mathrm{Cr}(\mathrm{VI})$ and water insoluble $\mathrm{Cr}(\mathrm{VI})$ correspond to less than one-tenth of each OEL value set by ACGIH. Matczak and Chmielnicka ${ }^{39)}$ reported that large amount of $\mathrm{Cr}(\mathrm{VI})$ was produced during manual metal arc stainless steel welding. Thus, the formation of $\mathrm{Cr}(\mathrm{VI})$ is considered to depend upon welding methods, materials and electrodes. The toxicity of $\mathrm{Cr}(\mathrm{III})$ is known to be much lower than $\mathrm{Cr}(\mathrm{VI})^{37)}$, and perforated nasal septum in welders ${ }^{38}$ is thought to be caused by inhalation of hexavalent chromium. Therefore, it may not be irrational to infer that chromium toxicosis in welders is associated with the predominance of hexavalent- or trivalent-chromium in welding fumes, which depends on the redox state of vaporized metallic chromium around the inert gas-shielded arc environment.

A local exhaust system has not been usually used in the welding workplace, because the high wind capture velocity for the local exhaust system often deteriorates the quality of the welded materials. However, it was reported that the low capture velocity of welding fumes in a local exhaust system would allow effective removal of welding fumes without such deterioration ${ }^{40)}$. Use of such a local exhaust system is considered to be effective to protect welders from inhalation exposure to welding fumes.

\section{Combined exposures to welding fumes and gases}

Health risks at work in combined exposure to welding fumes and gases can be assessed by the following equation ${ }^{20)}$, where $C_{i}$ and $T_{i}$ are the mean exposure concentration for each component $i$, and the threshold limit value for each component $i$, respectively. $C_{M n}, C_{C r(I I I)}, C_{\text {soluble } \mathrm{Cr}(V I)}, C_{\text {insoluble }}$ ${ }_{\mathrm{Cr}(V I)}, C_{O 3}, C_{C O}$ and $C_{N O}$ are the concentrations of $\mathrm{Mn}, \mathrm{Cr}(\mathrm{III})$, water soluble $\mathrm{Cr}(\mathrm{VI})$, water insoluble $\mathrm{Cr}(\mathrm{VI}), \mathrm{O}_{3}, \mathrm{CO}$ and NO, respectively. $T_{M n}, T_{C r(I I I)}, T_{\text {soluble } C r(V I)}, T_{\text {insoluble } C r(V I)}, T_{O 3}$, $T_{C O}$ and $T_{N O}$ are the occupational exposure limits of $\mathrm{Mn}$, $\mathrm{Cr}(\mathrm{III})$, water soluble $\mathrm{Cr}(\mathrm{VI})$, water insoluble $\mathrm{Cr}(\mathrm{VI}), \mathrm{O}_{3}$, $\mathrm{CO}$ and NO, respectively.

$$
\begin{aligned}
I=\sum \frac{C_{i}}{T_{i}}= & \frac{C_{M n}}{T_{M n}}+\frac{C_{C r(I I I)}}{T_{C r(I I I)}}+\frac{C_{\text {soluble } C r(V I)}}{T_{\text {soluble } C r(V I)}} \\
& +\frac{C_{\text {insoluble } C r(V I)}}{T_{\text {insoluble } C r(V I)}}+\frac{C_{O 3}}{T_{O 3}}+\frac{C_{C O}}{T_{C O}}+\frac{C_{N O}}{T_{N O}}
\end{aligned}
$$

This equation assumes additivity of toxicity in combined exposure to a mixture of substances. The $I$ values calculated by the above equation for the $\mathrm{CO}_{2}$-arc welding operation with the three kinds of wires were given 46.0 for the fluxcored wire, 18.6 for the solid wire and 20.8 for the Cr-Mo wire. All the $I$ values were found to greatly exceed the excursion limit ( $3 \times$ unity: 3.0 ), i.e., the limit for the combined exposure to welding fumes and gases. In many welding workplaces, half-facepiece dust respirators are often used, and protection factors of these respirators are reported to range from 5 to $10^{41)}$. This reveals that these welders can not be effectively protected only by wearing such halffacepiece dust respirators, and that supplied-air respirators with protection factors of greater than 50, or full-facepiece respirators with a high-efficiency particulate filter with protection factor of 50, are needed for arc welding. The airborne levels of $\mathrm{CO}$ emanating from the arc welding was found to exceed 3 times TLV-TWA, and dust respirators do not provide effective protection from exposure to $\mathrm{CO}$. 
Therefore, in order to effectively protect welders from combined exposure to welding fumes and gases, use of the supplied-air respirator, or combined use of a half-facepiece dust respirator and a local exhaust system, is recommended.

\section{References}

1) National Institute for Occupational Safety and Health (1988) Criteria for a recommended standard: welding, brazing and thermal cutting, DHHS (NIOSH) Publication No. 88-110.

2) Coggon D, Inskip H, Winter P, Pannett B (1994) Lobar pneumonia, an occupational diseases in welders. Lancet 344, 41-3.

3) Barhad B, Teculescu D, Cracium O (1975) Respiratory symptoms, chronic bronchitis and ventilatory function in shipyard welders. Int Arch Occup Environ Health 36, 137-50.

4) Flechig R (1988) What do we Know today about welding-fumes effects on the respiratory system? Industrial Health 26, 93-100.

5) Wolf C, Pirich C, Valic E, Waldhoer T (1997) Pulmonary function and symptoms of welders. Int Arch Occup Environ Health 69, 350-3.

6) Donoghue AM, Glass WI, Herbison GP (1994) Transient changes in the pulmonary function of welders: a cross sectional study of Monday peak expiratory flow. Occup Environ Health 51, 553-6.

7) Ohmori K, Tozawa T, Ikemi Y, Kobayashi Y, Kitazume M (1981) Pulmonary function observed by means of flow-volume curve in welders exposed to ozone. Jpn J Ind Health 23, 394-400 (In Japanese).

8) Ulfvarson U, Tech D (1981) Survey of air contaminations from welding. Scand J Work Environ Health 7 suppl 2, 1-28.

9) Wal JF (1985) Exposure of welders to fumess, $\mathrm{Cr}, \mathrm{Ni}$, $\mathrm{Cu}$ and Gases in Dutch Industries. Ann Occup Hyg 29, 377-89.

10) Japanese Standard Association (1976) Continuous analyzer for oxidants in ambient air. JIS B 7957-1976.

11) Japanese Standard Association (1986) Continuous analyzer for carbon monoxide in ambient air. JIS B 7951-1986.

12) Isobe $M$ (1984) Today's electrochemical gas sensor. Sensor Gijutsu 4 (13), 27-32 (In Japanese).

13) Sedlak JM, Blurton KF (1976) The electrochemical reactions of carbon monoxide, nitric oxide, and nitrogen dioxide at gold electrodes. J Electrochem Soc, Oct 1976,
1476-8.

14) Bay HW, Blurton KF, Sedlak JM, Valentine AM (1974) Electrochemical technique for the measurement of carbon monoxide. Anal Chem 46, 1837-9.

15) Kimura K (1978) On the T.R (total and respirable) dust Sampler (Rep. 1). J. Science of Labour 54, 11-8 (In Japanese).

16) Andersen AA (1966) A sampler for respiratory health hazard assessment. Am Ind Hyg Assoc J 27, 160-5.

17) Sawatari K, Serita F (1986) Determination of chromium speciation in fumess prepared by a plasma metal sprayer as a model of actual welding fumess. Industrial Health 24, 51-61.

18) American Conference of Governmental Industrial Hygienists (1999) 1999 TLVs and BEIs, ACGIH.

19) American Conference of Governmental Industrial Hygienists (1998) Guide to occupational exposure values - 1998, ACGIH.

20) Committee for Recommendation of Occupational Exposure Limits (1999) Recommendation of occupational exposure limits (1999-2000), J Occup Health 41, 191-206.

21) McDonnel WF, Horstman DH, Hazucha MJ, Seal E, Haak ED, Salaam SA, House DE (1983) Pulmonary effects of ozone exposure during exercise: dose-response characteristics. J Appl Physiol 54, 1345-52.

22) McDonnel WF, Kehrl HR, Abdul-Salaam S (1991) Respiratory response of humans exposed to low levels of ozone for 6.6 hours. Arch Environ Health 46, 14550.

23) Horstman DH, Folinsbee LJ, Ives PJ, Abdul-Salaam S, McDonnell F (1990) Ozone concentration and pulmonary response relationships for 6.6-hour exposure with five hours of moderate exercise to $0.08,0.10$, and $0.12 \mathrm{ppm}$. Am Rev Respir Dis 142, 1158-63.

24) Lunau FW (1967) Ozone in arc welding. Ann Occup Hyg 10, 175-88.

25) Frant $R$ (1963) Formation of ozone in gas-shielded welding, Ann Occup Hyg 6, 113-25.

26) Avol EL, Linn WS, Wightman LH, Homer JE, Hackney JD (1982) Laboratory evaluation of a disposable halfface mask for protection against ozone. Am Rev Respir Dis 126, 818-21.

27) Johnston AR, Dyrud JF, Shin YT (1989) Ozone removal capability of a welding fumes respirator containing activated charcoal. Am Ind Hyg Assoc J 50, 451-4.

28) Tsuchihana Y, Koike S, Ohmori K (1988) Carbon monoxide and fumes on the $\mathrm{CO}_{2}$-arc welding process. 
Jpn J Ind Health 30, 48-9 (In Japanese).

29) Peterson JE, Stewart RD (1970) Absorption and elimination of carbon monoxide by inactive young men. Arch Environ Health 21, 165-71.

30) Ishikawa K (1976) Poisonous of carbon monoxide, Sangyo-Hoken Volume II, 180-7, Shinohara-Shuppan, Japan (In Japanese).

31) Chemical Society of Japan: Kagaku-Binran Basic Volume 4th Edition, Maruzen, Tokyo (In Japanese).

32) Mergler D, Huel G, Bowler R, Iregren Am Belanger S, Baldwin M, Tardif R, Smargiassi A, Martin L (1994) Nervous system dysfunction among workers with longterm exposure to manganese. Environ Res 64, 15180.

33) Yim HW, Kim JH, Phee YG, Koo JW, Lee KS, Park CY, Lee JW, Han SR, Jand HS (1998) An association between brain MRI and neurologic findings in welders exposed to manganese fumes. Korean J Occup Environ Med 10, 161-71.

34) Hong YS, Lim MA, Lee YH, Cheong HK, Kim JY, Lim HS, Lee JJ, Sa KJ, Kim JY (1998) Three cases of high signal intensity by brain magnetic resonance imaging in $\mathrm{CO}_{2}$ arc welders. Korean J Occup Environ Med 10, 290-8.
35) Kang DM, Park HC, Son HS, Park JH, Lee YJ (1998) The significance of increased signal Intensity in MR imaging among male welders. Korean J Occup Med 10, 41-52.

36) Boshnakova E, Divanyan H, Zlatarov I, Marovsky S, Kisyova K, Zanev D, Karav G, Marinova T (1989) Immunological screening of welders. J Hyg Epidemiol Immunol 33, 379-82.

37) Watanabe $S$, Miura $T$ (1988) Gendai roudou eisei handbook, 761-2 (In Japanese).

38) Lee CR, Ryu CI, Lee JH, Kang JH, Kang SK, Yang JS, Shin YC (1998) Nasal septum perforation of welders. Korean J Occup Med 10, 404-11.

39) Matczak W, Chmielnicka J (1993) Relation between various chromium compounds and some other elements in fumess from manual metal arc stainless steel welding. Brit J Ind Med 50, 244-51.

40) Japan Welding Engineering Society (1995) The investigation on the relationship between the condition of the local air exhaust system and the blowhole. Yousetsu no Kenkyu 34, 105-42 (In Japanese).

41) National Institute for Occupational Safety and Health (1997) Pocket guide to chemical hazards, p. xxv-xxx. 